\title{
Ministry Involvement of Church Staff and Volunteers: The Role of Organizational Commitment and Work Engagement
}

\author{
David R. Dunaetz and Julie Bocock
} Azusa Pacific University

\begin{abstract}
One of the main functions of church leadership in the New Testament is to help people participate in ministry by serving others. However, church leaders may find it difficult to motivate lay volunteers, and even church staff, to do so. What are the factors that motivate ministry involvement? This paper examines the possible role of affective organizational commitment (the degree of emotional attachment to an organization) and work engagement (the degree to which one is immersed in and energized by one's work) as motivating factors. A study of church members involved in ministry ( $\mathrm{N}=336)$, including both lay volunteers and paid staff, was conducted to test whether both affective organizational commitment and work engagement predict ministry involvement. The results indicate that both organizational commitment and work engagement contribute to predicting ministry involvement of church staff and lay members. This relationship is true regardless of gender, tenure in the church, or church size. Work engagement is especially important for paid staff compared to lay volunteers. These results indicate that church leaders need to not only encourage commitment, but also to make sure that ministry is engaging and energizing for those who are serving.

Keywords: organizational commitment, ministry involvement, work engagement

One of the major functions of church leaders whom Christ has given to the church is "to equip his people for works of service" (Eph 4:12, NIV). Such equipping may include developing the knowledge, skills, and abilities of individual Christians so that they may better serve the Lord, but it might also include providing and developing the motivation necessary so that individuals use their gifts to serve the Lord in their specific context. Church leaders may find it difficult to provide this motivation to church members, and even church staff. This study
\end{abstract}


examines some of the motivating forces that may lead to ministry involvement, specifically, affective organizational commitment (Allen \& Meyer, 1990; Cohen, 2013; Meyer \& Allen, 1991) and work engagement (Bakker et al., 2008; Christian et al., 2011; Schaufeli et al., 2006). Such motivating forces may be, but are not necessarily, related to one's commitment to Christ which should be the underlying motivational force for service in the church.

The field of organizational psychology provides a number of tools for understanding how people think, feel, and behave in organizational contexts (Schein, 1965; Spector, 2017). Because Christ has called Christians to live in community, that is, in an organization known as church (Matt 16:18, Eph 2:19-22, Col 1:18), and because this life together is to be characterized by love (Jn 13:34-35, I Jn 4:7), the thoughts, feelings, and behaviors of church members are some of the primary aspects of church life that should concern church leaders. If the church members are genuinely born again (John 3:3), the Sprit transforms the life of the individuals; however, the communities that these individuals form still have the same dynamics which make the study of secular organizations possible, specifically, patterns of intrapersonal and interpersonal processes that tend to produce specific outcomes. Two topics often studied in organizational psychology are organizational commitment (the attitude that motivates members of an organization to remain part of the organization) and work engagement (a state of mind characterized by the desire to be immersed in one's work). A study of such topics does not deny that spiritual transformation exists; it simply does not examine the effects of such a transformation. Similarly, studying churches as organizations, that is, groups of individuals working toward a common purpose with some sort of decision making structure, does not deny that the church exists in other forms, such as the universal church, the set of all believers over all of time who have put their faith in Christ, or the church invisible, the subset of people associated with religious organizations who have been genuinely converted through their faith in Christ and have received the Holy Spirit.

Both organizational commitment and work engagement are known predictors of organizational effectiveness in general contexts (Christian et al., 2011; Meyer \& Allen, 1997; Meyer et al., 1989). Since church leaders are responsible for enabling church members to minister to others, understanding the factors that lead to ministry involvement may help them achieve this goal. This study will examine the relationship between organizational commitment, work engagement, and ministry involvement. Because ministry in contemporary North American churches is often carried out by both paid staff and volunteers, we will examine this relationship among both church staff and church volunteers involved in ministry.

In this exploratory study, we hypothesize, first, that both organizational commitment and work engagement predict ${ }^{1}$ ministry involvement. Second, we hypothesize that work engagement predicts ministry involvement over and beyond that predicted by organizational commitment. This would mean that both commitment and engagement contribute independently to motivating ministry involvement.

\section{Organizational Commitment}

Commitment to one's church relates to a number of concepts which play a central role in the New Testament such as meeting with other Christians to encourage one another to live for Christ (Heb 10:24-25) and demonstrating one's faith in a community setting (Jas 2:14-26).

\footnotetext{
${ }^{1}$ When multiple linear regression (or simply linear regression) is used in statistical modeling of phenomenon, i.e. $y$ $=b_{1} x_{1}+b_{2} x_{2}+\ldots b_{n} x_{n}$, where $y$ is the phenomena being predicted and $x_{i}$ are the phenomena used to predict $\mathrm{y}$, such models are considered correlational and do not demonstrate causation.
} 
Because the church is the body of Christ (Rom 12:5; 1 Cor 3:17; Eph 2:21; 4:16; Col 1:18, 24), commitment to Christ implies commitment to the church. Church leaders are responsible for helping Christians live out this commitment to Christ through service to others (Eph 4:11-12).

In the social sciences, organizational commitment (whether to a for-profit organization, or to a nonprofit, such as a church) has been defined as a "sense of attachment and loyalty" to an organization (Cohen, 2013, p. 526). It has been extensively studied in various organizational settings (Allen \& Meyer, 1990; Meyer \& Allen, 1991; Meyer et al., 2002), including churches (Berry, 2008; Dunaetz et al., 2018) where it has been conceptualized as church commitment, "A Christian's sense of attachment and loyalty to the church that he or she attends most frequently" (Dunaetz et al., 2018, p. 126). Some of the factors that lead to organizational commitment include shared values with those who are in leadership, satisfaction with the work one is doing, and the quality of relationships one has with other members of the organization (Cohen, 2013). Some of the consequences of organizational commitment include a willingness to sacrifice for the well-being of the organization, better work performance, and lower absenteeism (Cohen, 2013; Riketta, 2002; Tett \& Meyer, 1993). Greater church commitment in paid staff is associated with the head pastor's use of best practices in leadership (Berry, 2008) and, in lay members, with smaller churches, perceived pastoral humility, and longer church tenure (Dunaetz et al., 2018).

Organizational commitment is a sense of attachment and loyalty to an organization, such as a church. It is often measured as a multidimensional construct with three principle dimensions: affective commitment (one's emotional attachment to the organization; how much one wants to stay in it), continuance commitment (one's felt need to stay in an organization because of the costs associated with leaving), and normative commitment (the degree that one feels the moral need to be in the organization; Allen \& Meyer, 1990; Meyer \& Allen, 1991). The focus in this study is affective organizational commitment, the dimension of organizational commitment which is most closely related to work performance (Iverson \& Buttigieg, 1999). In this case, it is a measure of how much one likes one's church, wants to participate in it, and is committed to its values and members.

\section{Work Engagement}

Both volunteers and staff find some kinds of ministry-focused work more motivating, fun, interesting, or energizing than others. The psychological state created by such ministry is called work engagement (Bakker et al., 2008; Christian et al., 2011). Traditionally, psychological science has studied problems that humans experience. Workplace examples include burnout (Maslach \& Jackson, 1981) and workaholism (Spence \& Robbins, 1992). However, the developing field of positive psychology (Seligman et al., 2005) focuses on what goes right in human thought, feelings, and behavior. In work and in ministry, engagement is the term used to describe what people generally want to experience when carrying out their duties. The phenomena has usually been studied among salaried employees, but the same psychological processes come into play among volunteers (Vecina et al., 2012), such as those who serve in churches.

Work engagement has been defined as "a positive, fulfilling, affective motivational state of work-related well-being that is characterized by vigor, dedication, and absorption" (Bakker et al., 2008, p. 187). It occurs when the volunteer or employee feels a positive emotional connection to the work and desires to invest more of his or her energy into it. This connection is to the work itself, not to the church or any other organization nor to the position of responsibility 
that the person has. The work itself is engaging and energizing, so the volunteer or staff member is motivated to continue it simply because it is enjoyable.

Engaging work is characterized by vigor, dedication, and absorption. Vigor describes work done with a high level of energy, a willingness to invest effort into it, and persistence in the face of difficulties. Dedication is characterized by a commitment to the work because the volunteer or staff member senses its significance, is inspired by it, and feels enthusiasm toward it. Absorption occurs when one has the feeling of being engrossed in the work, when the work is fun and enjoyable, and when it is difficult to pull away from because other options are less attractive (Bakker et al., 2008; Schaufeli et al., 2006). Originally, it was believed that vigor, dedication, and absorption would be independent dimensions of work engagement. However, studies indicate that the three tend to go together; it is rare for work to be strongly characterized by one, but not the others (Schaufeli et al., 2006). Work engagement is experienced across all fields of work. Not all ministry is engaging, but most Christian workers and volunteers have been involved in some form of engaging ministry, seeing the glory of God in it and experiencing the motivation necessary to continue (John 4:35-38, Rom. 1:16).

Work (or ministry) engagement is similar to, but different than, other work-related concepts, such as organizational commitment and job satisfaction. Organizational commitment as described previously, and especially the dimension of affective organizational commitment, defined as "an emotional attachment to one's organization that results from shared values and interests" (Christian et al., 2011, p. 97; Mowday, 1998), tends to be fairly strongly correlated with work engagement. However, organizational commitment focuses on the organization as a whole, whereas work engagement focuses specifically on the work that the individual is doing as part of his or her job (Christian et al., 2011). In church contexts, organizational commitment would refer to commitment to the church as a whole, the community and the institution which is part of Christ's body (I Cor. 12:12-14, Eph. 4:1-16), whereas work engagement refers to one's experience in a specific ministry.

Job satisfaction (Tett \& Meyer, 1993; Weiss, 2002) is another concept similar to work engagement. Job satisfaction can be defined as the "positive (or negative) evaluative judgment one makes about one's job or job situation" (Weiss, 2002, p. 97). Job satisfaction is a global evaluation of one's job conditions or characteristics whereas engagement describes one's experience while doing work. In ministry, job satisfaction may come from knowing one is doing God's will or from the positive relationships that one has with others in the church or ministry. Work engagement, in contrast, is due to the nature of the specific ministry that one is carrying out.

Work engagement also shares some characteristics with workaholism, "the compulsion or the uncontrollable need to work incessantly" (Oates, 1971, p. 11). Both are associated with extended periods of time spent working and higher quality work, but workaholism results primarily from the personality and situation of the employee whereas work engagement is primarily a function of the nature of the work. Workaholism tends to have negative consequences on one's social relations and health whereas work engagement is associated with positive outcomes in these areas (Schaufeli et al., 2008).

Factors Contributing to Work Engagement. Several sets of factors have been empirically identified to contribute to work engagement. Job characteristics, leadership, and personality may all contribute to how engaging one finds one's work (Christian et al., 2011; Macey \& Schneider, 2008). 
Job characteristics that motivate a person to want to accomplish the work are the primary drivers of engagement. This motivation might come from characteristics that reduce the psychological and physiological costs involved in performing the job, help in achieving the goals associated with the job, or promote personal growth and learning (Bakker \& Demerouti, 2008). Autonomy is one of these job characteristics. Having control over how one does one's job, along with sufficient information to do it, promotes ownership and creativity in one's work resulting in engagement. Task variety, having enough novelty in one's responsibilities, also promotes work engagement. The degree to which the job is meaningful, specifically, the degree to which it positively affects others (including God), influences how engaging the work is. In addition, jobs that provide feedback about the quality of the work being done, jobs that are complex and multifaceted, and jobs that require problem solving and creativity tend to be more engaging than jobs that do not have these characteristics (Christian et al., 2011).

The social and physical characteristics of the job are also important. When social support, such as assistance, useful advice, encouragement, or any other type of positive interaction, is provided by coworkers, the job tends to be more engaging. Similarly, optimal physical characteristics of a job contribute to engagement: Work areas that are neither too hot nor too cold, physical demands that are neither too sedentary nor too demanding of exertion, an environment that is neither too quiet nor too loud. Any type of discomfort, social or physical, reduces workers' motivation to invest in their work (Bakker \& Demerouti, 2008; Christian et al., 2011).

The degree to which people are engaged in their work is also affected by those in leadership. Leaders who express a lot of positive affect and charisma create more passion in those under them than do more subdued leaders. Similarly, employees who have a high quality relationship with their supervisor tend to be more engaged (Christian et al., 2011; George, 2000). Even the quality of supervisors' sleep has been found to predict employees' work engagement; well-rested supervisors tend to treat employees more fairly which creates a more engaging work environment for employees (Barnes et al., 2015). In fact, work engagement increases any time that a supervisor treats employees more fairly; treating employees more fairly engenders trust in the supervisor which in turn motivates employees to pour themselves more completely into their work (Agarwal, 2014).

At the same time, some workers are more dispositionally prone to work engagement than others are. Staff and volunteers who are more conscientious, more positive and upbeat, and more goal-oriented tend to have higher levels of job engagement than those who are lower in these traits (Bakker et al., 2012; Christian et al., 2011).

Consequences of Work Engagement. Besides making work more agreeable for the worker, previous research has found other important consequences of work engagement (Bakker $\&$ Demerouti, 2008). Staff and volunteers who are engaged produce higher quality work than those who are not (Salanova et al., 2005). This occurs for several reasons. Workers with more positive emotions, such as those found in engaged workers, are more motivated to work harder and longer, leading to higher quality work (Fredrickson, 2001, 2003). Work engagement is associated with better psychological and physical health, which enables workers to persist when difficulties are encountered, and motivates them to use more of their resources (physical, social, psychological, etc.) to get the job done. Work engagement is also associated with the creation of new resources, a process known as job-crafting (Bakker et al., 2014; Tims et al., 2013), which involves choosing which tasks to focus on, negotiating one's responsibilities, and adjusting the 
work chosen to perform so that it is the most meaningful. Engaged workers tend to craft their jobs so that they end up doing what is the most effective, impactful, and meaningful.

An especially important consequence of job engagement in ministry contexts concerns the service recipients. Engaged workers tend to have a greater positive impact on those receiving their services than do those who are less engaged (Salanova et al., 2005). In business contexts, this translates into greater customer satisfaction and loyalty. In the local church, this may translate into more effective ministry, better communication of the Word of God, and transformed lives.

On a personal level, engaged workers have higher organizational commitment and job satisfaction (Schaufeli et al., 2008). Their mental and physical health is better, experiencing less burnout, depression, and anxiety (Hakanen et al., 2006; Schaufeli et al., 2008). They also have better relations with coworkers and receive more social support. This is because they express more positive emotions, motivate others to join in the work, and make extra efforts to make sure that the work environment is positive (Bakker et al., 2004; Bakker et al., 2008). Certainly, it could be argued that for Christians such behaviors should occur naturally because of what they have experienced in Christ. However, "the spirit is willing, but the body is weak" (Matt. 26:41b, NIV). It is quite possible that engaging work may have a positive impact on Christian's involvement in ministry.

\section{Hypotheses}

One of the main reasons Christian leaders are involved in ministry is because of their love for the Lord. Service in the local church, that is, the local manifestation of the body of Christ, is thus an expression of one's love for the Lord. For this reason, our first hypothesis is that organizational commitment, specifically affective organizational commitment that measures a person's emotional attachment and loyalty to a church, will be related to church involvement. This should be true for both professional church staff and volunteer lay leaders.

Hypothesis 1: For both church staff members and volunteer lay leaders, affective organizational commitment will be positively correlated with ministry involvement.

At the same time, Christian leaders are human and need motivation to persist in their service. For this reason, we hypothesize that work engagement will also predict the level of a leader's involvement in ministry. When ministries are less engaging, it is likely that leaders will be more easily distracted by other things and less willing to commit their time and energy resources to such ministries.

Hypothesis 2: For both church staff members and volunteer lay leaders, work engagement will be positively correlated with ministry involvement.

Although it is likely that affective organizational commitment and work engagement are highly correlated in ministry contexts, it is possible that both contribute independently to ministry engagement. This would mean that one without the other would result in less ministry involvement and that maximum levels of both would be expected to result in the most ministry involvement. Thus, the third hypothesis will specifically examine if work engagement 
contributes to ministry involvement beyond the contribution of affective organizational commitment.

Hypothesis 3: For both church staff members and volunteer lay leaders, both affective organizational commitment and work engagement will independently contribute to ministry involvement.

All three of these hypothesized relationships should hold true regardless of the gender or tenure of the worker or the size of the church.

The purpose of this study is to better understand how work engagement and organizational commitment, specifically affective organizational commitment, are related to ministry involvement in both church staff and lay volunteers. This understanding will enable Christian leaders to better develop emerging leaders and design ministries to more effectively enable people to serve the Lord.

\section{Method}

To test the hypotheses, an online survey was used to collect data from people involved in ministry, both as paid church staff and as lay volunteers. Participants answered a series of questions about their ministry experiences, which measured all of the key concepts in the study.

\section{Participants}

Participants were recruited using a convenience sample beginning with the social network of the junior researcher, which was enlarged with a snowball sampling technique (Baltar $\&$ Brunet, 2012; Goodman, 1961). Members of her social network were encouraged to distribute the web link to the survey to members of their own social networks. To participate in the survey, respondents needed to regularly attend a church and be either employed by the church ( $\operatorname{staff}, \mathrm{n}=$ 87 ) or volunteer in some sort of ministry (volunteers, $n=249$ ). A total of 336 participants provided usable data. In addition, there were 9 participants who started the survey but did not complete it or did not provide meaningful data.

The participants came from 32 states; the most represented were California (52.1\%), New Mexico (7.1\%), and Florida (5.4\%). Eleven participants reported living outside the US, primarily in Mexico or Australia; it is possible that this includes American missionaries or others with ties to American evangelical culture since participants were recruited in light of their church participation, beginning with American church attenders. The average age was 42.6 years and $70.2 \%$ were female. Concerning race and ethnicity, $82.1 \%$ identified as White, $10.4 \%$ as Hispanic or Latino, 3.2\% as Asian, 3.2\% as African American, and 3.7\% as other.

\section{Measures}

Organizational Commitment. Participants responded to 8 statements using a 5-point Likert scale ( 1 = Strongly Disagree, 5 = Strongly Agree) adapted from Meyer and Allen's (1991) Affective Organizational Commitment scale. Items were modified to measure church commitment rather than a more general affective organizational commitment, as in previous studies of churches (Dunaetz et al., 2018; Dunaetz et al., 2020), by replacing the word organization with church. Items measuring church commitment included "I would be very happy to spend the rest of my career with this church" (original item, "I would be happy to spend the 
rest of my career with this organization") and "I think that I could easily become as attached to another church as I am to this one" (reverse scored; original item, "I think I could easily become as attached to another organization as I am to this one"). The coefficient of reliability was excellent $(\alpha=.875)$, indicating that the modified scale measured a single, unified concept.

Work Engagement. Participants were asked to respond to nine statements describing their experiences working at their church as either an employee or volunteer $(1=$ Never, $5=$ Always). The items were modified from the short version of the Utrecht Work Engagement Scale (UWES-9; Schaufeli et al., 2006). These statements included "I am enthusiastic about the work that I do at my church." and "I feel happy when I am immersed in my work at church." The coefficient of reliability was excellent $(\alpha=.914)$.

Ministry Involvement. Two questions measured ministry involvement, both focusing on the frequency of activity $($ Never $=1, \ldots$ Monthly $=4, \ldots$ Several times per week $=7)$ : "How often do you serve as a volunteer or serve others in your church?" and "How often do you attend worship services, meetings, etc. at your church?" The responses to these two questions were significantly correlated $(r=.38, p<.001)$. Involvement was calculated to be the average of the responses to the questions. Because the responses were highly negatively skewed (i.e., average scores much higher than the scale midpoint) for both lay leaders and paid staff (skewness $<-1.6$ ), all analyses were recalculated with involvement as a relatively symmetrically distributed dichotomous variable ( 0 for initial values less than $6.5,1$ for initial values of 6.5 and above). This logistic regression analysis indicated no significant differences compared to the original linear regression that is presented in the Results section.

Church Size. One item using an 8-point scale measured perceptions of the size of one's church. $(1=$ less than $50,8=10,000+)$. The median church size was 4 (201-500 people). The average church size was 4.36 (between 201-500 people and 501-1000 people).

Tenure. One item measured how long the participant had attended his or her church ${ }^{2}$. The average church tenure was 12.4 years.

Age. One item measured the age of participants. The average age of participants was 42.7 years.

Gender. Participants indicated whether they were male, female, or "Other or prefer not to state." Only 2 participants chose the third response. However, several respondents did not complete the optional demographic items of the survey.

Race/Ethnicity. Participants were given a range of choices concerning race and ethnicity. They were able to choose more than one or specify a race or ethnicity not on the list.

\footnotetext{
${ }^{2}$ Note that church tenure is very different than the length of time since one's conversion. Many people were converted before they started attending their present church. Others who attend a church may not be converted at all. Time since a person's conversion is an interesting variable and is worthy of inclusion in future research.
} 


\section{Results}

Descriptive statistics of the main variables are presented in Table 1. It should be noted that staff expressed significantly higher levels (compared to volunteers) of church commitment $\left(M_{\text {staff }}=4.04, M_{\mathrm{vol}}=3.81, t(334)=2.58, p=.010\right.$, two tails $)$, work engagement $\left(M_{\text {staff }}=3.99\right.$, $M_{\mathrm{vol}}=3.54, t(334)=5.84, p<.001$, two tails $)$, and involvement $\left(M_{\text {staff }}=5.64, M_{\mathrm{vol}}=5.43, t(334)\right.$ $=2.14, p=.03$, two tails). Staff and volunteers did not differ significantly in age $(M=43$ years $)$, church tenure ( $M=12.4$ years), or size of church (between 201-500 people and 501-1000 people). The intercorrelations of the main variables are found in Table 2.

Table 1

Means, Standard Deviations, and Ranges of Main Variables

\begin{tabular}{|c|c|c|c|c|c|c|c|c|}
\hline \multirow[b]{2}{*}{ Measure } & \multicolumn{3}{|c|}{ Lay Volunteers $(n=249)$} & \multicolumn{3}{|c|}{ Staff $(n=87)$} & \multicolumn{2}{|c|}{ Total } \\
\hline & $M$ & $S D$ & Range & $M$ & $S D$ & Range & $M$ & $S D$ \\
\hline Commitment & 3.81 & .73 & $1.75-5.00$ & 4.04 & .64 & $2.00-4.88$ & 3.87 & .71 \\
\hline Engagement & 3.54 & .65 & $1.44-5.00$ & 4.00 & .56 & $2.33-5.00$ & 3.66 & .65 \\
\hline Involvement & 5.43 & .78 & $2.00-6.00$ & 5.65 & .75 & $3.00-6.00$ & 5.49 & .78 \\
\hline Church Size & 4.27 & 1.80 & $1-8$ & 4.61 & 2.00 & $1-7$ & 4.36 & 1.86 \\
\hline Tenure & 12.37 & 11.82 & $0-52$ & 12.40 & 9.97 & $0-50$ & 12.38 & 11.35 \\
\hline Age & 42.88 & 13.22 & $18-80$ & 41.98 & 13.47 & $18-67$ & 42.65 & 13.27 \\
\hline Gender & .74 & .44 & $0-1$ & .60 & .49 & $0-1$ & .71 & .46 \\
\hline
\end{tabular}

Note. $N=336$. Tenure and age are in years. For gender, male $=0$, female $=1$.

Table 2

Correlations of Main Variables

\begin{tabular}{llllllc}
\hline Measure & 1 & 2 & 3 & 4 & 5 & 6 \\
\hline 1. Commitment & -- & & & & & \\
2. Engagement & $.67 * * *$ & -- & & & & \\
3. Involvement & $.39 * * *$ & $.45 * * *$ & -- & & & \\
4. Church Size & -.08 & .08 & -.02 & -- & & \\
5. Tenure & $.21 * * *$ & .03 & .02 & .04 & -- & \\
6. Age & .10 & .03 & .00 & $-.12 *$ & $.32 * * *$ & -- \\
7. Gender & -.03 & -.07 & $-.13 *$ & -.02 & .00 & -.05 \\
\hline
\end{tabular}

Note. $N=336,{ }^{*} p<.05, * * * p<.001$. For gender, male $=0$, female $=1$.

Hypothesis Testing. The first hypothesis, which stated that affective organizational commitment would be positively correlated with ministry involvement, was supported (Table 2). This was true for both church staff $(r=.26, d f=85, p=.009$, one tail) and lay volunteers $(r=$ $.41, d f=247, p<.001$, one tail).

The second hypothesis, which stated that work engagement would be positively correlated with ministry involvement, was supported (Table 2). This was true for both church staff $(r=.48, d f=85, p<.001$, one tail) and lay volunteers $(r=.42, d f=247, p<.001$, one tail).

The third hypothesis stated that, for both church staff members and volunteer lay leaders, both affective organizational commitment and work engagement would independently contribute 
to ministry involvement. This hypothesis was tested with a stepwise multiple regression analysis. Multiple regression is a statistical technique to measure the contribution that the variation of each variable in a set of presumably causal variables (in this case, affective organizational commitment and work engagement) makes to a variable that is presumably the outcome of these causal variables. Although it cannot demonstrate causation, it can show what the driving forces are, if causation, in fact, exists. For example, ice cream consumption, the daily maximum temperature, and the local crime rate are all positively correlated; in the summer, they are all higher than in the winter. We could propose a model that says that crime is caused by ice cream consumption and warmer temperatures. If we collected data on the three variables, a multiple regression analysis would indicate the contribution of each of the presumed causes (ice cream consumption and warmer temperature) on the outcome variable (crime). In this example, all the variation would almost certainly be due to the temperature and none to ice cream consumption. Although there is much overlap between ice cream consumption, temperature, and crime, multiple regression would indicate that, once the overlap is removed, only temperature (and not ice cream consumption) predicts the crime rate. The strength of this relationship is called $\beta$.

The results of the stepwise multiple regression are presented in Table 3. The first step includes only commitment and engagement as predictors of involvement. The second step controls for the possible influence of church size, tenure, age, and gender. For the lay volunteers, Hypothesis 3 was supported; both affective commitment and work engagement predict involvement in ministry. However, among church staff, the hypothesis was only partially supported; work engagement predicts ministry involvement, but there is no significant contribution from affective commitment. These relationships remained significant even when controlling for church size, tenure, and gender.

Table 3

Predictors of Church Involvement

\begin{tabular}{|c|c|c|c|c|}
\hline & \multicolumn{2}{|c|}{ Lay Volunteers } & \multicolumn{2}{|c|}{ Staff } \\
\hline & $\beta$ & $\beta$ & $\beta$ & $\beta$ \\
\hline \multicolumn{5}{|l|}{ Step 1} \\
\hline Commitment & $.23 * *$ & $.20 *$ & -.02 & .00 \\
\hline Engagement & $.27 * * *$ & $.29 * * *$ & $.49 * * *$ & $.46 * * *$ \\
\hline \multicolumn{5}{|l|}{ Step 2} \\
\hline Church Size & & $-.13 *$ & & .17 \\
\hline Tenure & & -.01 & & .00 \\
\hline Age & & -.07 & & .09 \\
\hline Gender & & $-.14 *$ & & -.06 \\
\hline Total $R^{2}$ & $.21 * * *$ & $.25 * * *$ & $.23 * * *$ & $.27 * * *$ \\
\hline$n$ & 245 & 245 & 85 & 85 \\
\hline
\end{tabular}

Note. $* p<.05, * * p<.01, * * * p<.001$. For gender, male $=0$, female $=1$. 


\section{Discussion and Implications}

This study examined lay leader and pastoral staff involvement in church ministries. For both groups, affective organizational commitment (emotional attachment to the church) and work engagement (the desire to immerse oneself in one's ministry) predicted greater ministry involvement. For church staff, the role of work engagement was especially important.

\section{Lay Ministry}

For lay leaders, both affective organizational commitment and work engagement independently contributed to the degree to which lay leaders were involved in ministry. The more committed they were to the church and the more engaged they were in the ministry where they were serving, the more they got involved.

For church leaders who are responsible for helping lay people get involved in ministry (Eph. 4:11-12), this means that increasing affective commitment to the church should be a priority to motivate lay involvement in ministry. The church, as an organization, needs to be emotionally attractive to raise levels of affective commitment. This attractiveness can be influenced by many factors: the vision of the leadership team, the quality of the worship service, fidelity to the gospel, services offered to the community, the quality of relationships that members have with one another, among others (Dunaetz et al., 2018; Schwarz \& Schalk, 1996). This is not to deny that the Holy Spirit plays a role in influencing a person's feelings towards the church; however, the role of the Holy Spirit was not examined in this study.

Although many of the factors that lead to higher affective commitment to the church would be a reflection of biblical love and faithfulness, others would be determined by local culture and context. In designing church programs, leaders must remain faithful to essential biblical foundations, but must also work to contextualize the gospel so that people can see how it meets their needs in their specific context (Hesselgrave, 1989; Hiebert, 1987). As cultures evolve, such contextualization may create conflicts (e.g., "worship wars") but applying biblical principles of love, respect, and fairness can significantly reduce the negative consequences (Dunaetz, 2016).

Similarly, church leaders who are responsible for the church's various ministries need to make them as engaging as possible to motivate Christians to serve the Lord in them. Previous research (Bakker et al., 2014; Bakker et al., 2008; Schaufeli et al., 2008) provides many principles for making ministry engaging. First, lay people involved in ministry (e.g., Sunday School teachers) should be provided the material resources necessary to carry out their responsibilities; this would include well-maintained physical space and furnishings, technology, and high-quality curriculum. Second, they should receive encouraging performance feedback that enables them to know that they are having a positive impact on the recipients of their efforts; church staff need to pay attention and verbally express appreciation for the volunteers' work, encourage praiseworthy efforts, and provide relevant and high quality training, mentoring, and coaching. Third, it is essential that lay workers receive social support when involved in ministry; both coworkers and those over them should be listening to them, encouraging them, and responding in a supportive way to whenever the worker needs to discuss either ministry or personal matters. Ministry time and meetings need to be structured in such a way that coworkers may develop healthy and solid relationships with each other and express the needed support. Fourth, those responsible for programs need to avoid micromanaging the lay volunteers; they 
need to encourage job crafting so that volunteers can carry out their ministry in the way that best corresponds to their interests, skills, and gifting (I Cor 12:4-31). Those supervising them need to give them freedom, communicating that they are available to help in any way to make sure they succeed in their ministry. Again, this is not to deny that the Holy Spirit can make ministry engaging; the role of the Holy Spirit was simply not examined in this study.

\section{Church Staff}

In this study, among church staff members, both affective organizational commitment and work engagement were positively correlated with ministry involvement. However, commitment did not contribute to predicting ministry involvement beyond the contribution of work engagement. This implies that work engagement is the main driver of ministry involvement for staff members.

It is not hard to imagine how such a phenomenon may have played out in the life of the apostle Paul in relationship to the church of Corinth. Paul seems to have been more involved with the church of Corinth than with most of the other churches he planted (Garland, 2003; Thiselton, 2000). It appears that he wrote more to them (1 Cor, 2 Cor., the "previous letter" mentioned in 1 Cor 5:9, and perhaps the "severe letter" in 2 Cor 2:3-4), visited them more often (Acts 18:1-18, 20:3, 2 Cor 2:1, 12:14, 13:1), and stayed with them longer (Acts 18:11, 20:3) than was typical with other churches (Barnett, 1997). He was highly involved in ministry there and the passion with which he wrote to them indicates that he was highly engaged. However, the reader of 1 and 2 Corinthians does not get the impression that Paul had a high level of affective organizational commitment to the church. The church was the source of much pain for him. He discusses the pain he felt (2 Cor 2:1-4) and the attractiveness of avoiding them (2 Cor 1:15-24); he repeatedly feels the need to defend his own ministry to them (1 Cor 4, 2 Cor 1:8-2:4, 3:1-6, 10-13). Paul was primarily motivated to minister to the Corinthians because of how he saw God working among them (1 Cor 3:5-10) and because of their need (e.g., 1 Cor 1:10-12), not because it felt good to be with them, although this appears to be an outcome he desired (2 Cor 6:11-13; Barnett, 1997; Fee, 1987; Harris, 2005).

If the same factors affecting work engagement in more general populations influence church staff, staff may be provided the resources needed to carry out their ministry, performance feedback concerning the meaning and efficacy of their work, social support from those they see regularly, and autonomy to craft their jobs as they see fit in order to promote maximum work engagement. These may be provided by the senior pastor to subordinate staff, and by the board to the senior pastor. As for hiring decisions, candidates that are higher in conscientiousness and extraversion have been found to become more engaged in their work than those lower in these traits (Bakker et al., 2014; Christian et al., 2011). However, it is important to note that Christ's own apostles varied widely in their levels of extraversion and conscientiousness, as is observable in the contrast between John's engagement with Christ with Peter's at critical moments (e.g., John 13:23-25; 36-38; John 21:15-25; Mark 8:27-33); it was their commitment to and passion for Christ and his commission that ultimately motivated their ministry (John 14:15-25; Mt. 28:1920).

\section{Limitations}

A limitation of this study is that only several variables were measured to predict ministry involvement, resulting in models that only predicted about a quarter of its variance. Variables concerning individuals' present spiritual state, their faith in Christ, and spiritual maturity are 
among many others that were not examined. Including such variables in future studies may provide additional insights concerning ministry involvement.

As a correlational study, this study cannot determine the direction of causation in the relationships discovered. Just as engagement and commitment might cause people to become more involved in ministry, involvement in ministry may cause them to be more committed and engaged as the work progresses. It should be noted that only one type of commitment was examined, affective commitment to the church. Other types of commitment exist but were not examined in this study. Similarly, involvement was measured only as frequency of participation in activities. Future studies would do well to measure the quality of ministry involvement, which is at least as important as the frequency. It is especially important to keep in mind that the phenomena examined in this study, affective organizational commitment and work engagement, are likely to be secondary from a biblical point of view when compared to other elements of the Christian life, such as commitment to the Lord, faithfulness to his Word, sacrificial love for others, and godly living (Matt. 22:36-40, 2 Tim. 3:14-16, 2 Pet. 1:3-9).

The generalizability of this study is limited to the degree that the sample examined represents other populations. Because no sampling frame of church members involved in ministry (either lay or professional) was available, a convenience sample was used which included snowball sampling (Baltar \& Brunet, 2012; Goodman, 1961) rather than a probabilistic sampling strategy, limiting the generalizability. However, one of the major limitations of snowball sampling in organizations occurs only when participants are asked to collect data from supervisors or coworkers about the participants themselves (Marcus et al., 2017); this was not the case in this study, limiting the bias that such a sampling strategy might produce.

The relationships examined in this study are possibly moderated by culture. Cultural dimensions such as individualism/collectivism (Kim et al., 1994) and tightness/looseness (Dunaetz, 2019; Gelfand et al., 2006) respectively represent differences in self-concept and the appropriateness of social sanctioning. Such elements of culture may have an impact on the variables and relationships examined in this study. A majority of participants came from California, a state that is relatively high in both collectivism and cultural looseness (Harrington \& Gelfand, 2014; Vandello \& Cohen, 1999), indicating the sample in this study may not be culturally representative of other populations in the United States, nor in the rest of the world.

\section{Conclusion}

This study has sought to understand how Christian leaders can motivate staff and lay members to be involved in ministry, one of their most important duties (Eph. 4:11-13). Both affective organizational commitment (one's positive feelings toward the church) and work engagement (one's willingness to pour oneself into one's ministry) predicted greater ministry involvement. Work engagement was especially important for motivating church staff. Leaders can use this information to design ministry structures within the church to best "prepare God's people for works of service, so that the body of Christ may be built up until we all reach unity in the faith and in the knowledge of the Son of God" (Eph. 4:12-13a, NIV). 


\section{References}

Agarwal, U. A. (2014). Linking justice, trust and innovative work behaviour to work engagement. Personnel Review, 43(1), 41-73.

Allen, N. J., \& Meyer, J. P. (1990). The measurement and antecedents of affective, continuance and normative commitment to the organization. Journal of occupational psychology, 63(1), 1-18.

Bakker, A. B., \& Demerouti, E. (2008). Towards a model of work engagement. Career development international, 13(3), 209-223.

Bakker, A. B., Demerouti, E., \& Sanz-Vergel, A. I. (2014). Burnout and work engagement: The JD-R approach. Annual Review of Organizational Psychology and Organizational Behavior, 1(1), 389-411.

Bakker, A. B., Demerouti, E., \& Verbeke, W. (2004). Using the job demands-resources model to predict burnout and performance. Human Resource Management Review, 43(1), 83-104.

Bakker, A. B., Schaufeli, W. B., Leiter, M. P., \& Taris, T. W. (2008). Work engagement: An emerging concept in occupational health psychology. Work \& Stress, 22(3), 187-200.

Bakker, A. B., Tims, M., \& Derks, D. (2012). Proactive personality and job performance: The role of job crafting and work engagement. Human Relations, 65(10), 1359-1378.

Baltar, F., \& Brunet, I. (2012). Social research 2.0: virtual snowball sampling method using Facebook. Internet research, 22(2), 57-74.

Barnes, C. M., Lucianetti, L., Bhave, D. P., \& Christian, M. S. (2015). "You wouldn't like me when I'm sleepy": Leaders' sleep, daily abusive supervision, and work unit engagement. Academy of Management Journal, 58(5), 1419-1437.

Barnett, P. (1997). The Second Epistle to the Corinthians. William B. Eerdmans Publishing.

Berry, J. R. (2008). The relationships among leadership practices, organizational climate, and organizational commitment within church ministry settings. Regent University.

Christian, M. S., Garza, A. S., \& Slaughter, J. E. (2011). Work engagement: A quantitative review and test of its relations with task and contextual performance. Personnel Psychology, 64(1), 89-136.

Cohen, A. (2013). Organizational Commitment Theory. In E. H. Kessler (Ed.), Encyclopedia of Management Theory (Vol. 2, pp. 526-529). Sage Publications.

Dunaetz, D. R. (2016). Mission in Evolving Cultures: Constructively Managing Music-Related Conflict in Cross-Cultural Church Planting Contexts. Missiology: An International Review, 44(3), 296-310.

Dunaetz, D. R. (2019). Cultural tightness-looseness: Its nature and missiological applications. Missiology, 47(4), 410-421.

Dunaetz, D. R., Cullum, M., \& Barron, E. (2018). Church Size, Pastoral Humility, and Member Characteristics as Predictors of Church Commitment. Theology of Leadership Journal, $1(2), 125-138$.

Dunaetz, D. R., Smyly, C., Fairley, C. M., \& Heykoop, C. (2020). Values Congruence and Organizational Commitment in Churches: When Do Shared Values Matter? Psychology of Religion and Spirituality, Advance online publication.

Fee, G. D. (1987). The first epistle to the Corinthians. William B. Eerdmans Publishing.

Fredrickson, B. L. (2001). The role of positive emotions in positive psychology: The boradenand-build theory of positive emotions. American Psychologist, 56(3), 218-226. 
Fredrickson, B. L. (2003). Positive emotions and upward spirals in organizations. In J. E. Dutton, R. E. Quinn, \& K. S. Cameron (Eds.), Positive organizational scholarship (pp. 163-175). Berrett-Koehler.

Garland, D. E. (2003). 1 Corinthians. Baker Academic.

Gelfand, M. J., Nishii, L. H., \& Raver, J. L. (2006). On the nature and importance of cultural tightness-looseness. Journal of Applied Psychology, 91(6), 1225-1244.

George, J. M. (2000). Emotions and leadership: The role of emotional intelligence. Human Relations, 53(8), 1027-1055.

Goodman, L. A. (1961). Snowball sampling. The Annals of Mathematical Statistics, 32(1), 148170.

Hakanen, J. J., Bakker, A. B., \& Schaufeli, W. B. (2006). Burnout and work engagement among teachers. Journal of school psychology, 43(6), 495-513.

Harrington, J. R., \& Gelfand, M. J. (2014). Tightness-looseness across the 50 United States. Proceedings of the National Academy of Sciences, 111(22), 7990-7995.

Harris, M. J. (2005). The second epistle to the Corinthians: a commentary on the Greek text. William B. Eerdmans.

Hesselgrave, D. J. (1989). Contextualization: Meanings, Methods, and Models. Baker Book House.

Hiebert, P. G. (1987). Critical Contextualization. International Bulletin of Missionary Research, 11(3), 104-112.

Iverson, R. D., \& Buttigieg, D. M. (1999). Affective, normative and continuance commitment: can the 'right kind' of commitment be managed? Journal of Management Studies, 36(3), 307-333.

Kim, U. E., Triandis, H. C., Kâğitçibaşi, Ç. E., Choi, S.-C. E., \& Yoon, G. E. (1994). Individualism and collectivism: Theory, method, and applications. Sage Publications.

Macey, W. H., \& Schneider, B. (2008). The meaning of employee engagement. Industrial and organizational Psychology, 1(1), 3-30.

Marcus, B., Weigelt, O., Hergert, J., Gurt, J., \& Gelléri, P. (2017). The use of snowball sampling for multi source organizational research: Some cause for concern. Personnel Psychology, 70(3), 635-673.

Maslach, C., \& Jackson, S. E. (1981). The measurement of experienced burnout. Journal of occupational behavior, 2(2), 99-113.

Meyer, J. P., \& Allen, N. J. (1991). A three-component conceptualization of organizational commitment. Human Resource Management Review, 1, 61-89.

Meyer, J. P., \& Allen, N. J. (1997). Commitment in the Workplace: Theory, Research, and Application. Sage Publications.

Meyer, J. P., Paunonen, S. V., Gellatly, I. R., Goffin, R. D., \& Jackson, D. N. (1989).

Organizational commitment and job performance: It's the nature of the commitment that counts. Journal of Applied Psychology, 74(1), 152-156.

Meyer, J. P., Stanley, D. J., Herscovitch, L., \& Topolnytsky, L. (2002). Affective, continuance, and normative commitment to the organization: A meta-analysis of antecedents, correlates, and consequences. Journal of vocational behavior, 61(1), 20-52.

Mowday, R. T. (1998). Reflections on the study and relevance of organizational commitment. Human Resource Management Review, 8(4), 387-401.

Oates, W. E. (1971). Confessions of a workaholic: The facts about work addiction. World Publishing Company. 
Riketta, M. (2002). Attitudinal organizational commitment and job performance: A metaanalysis. Journal of Organizational Behavior, 23(3), 257-266.

Salanova, M., Agut, S., \& Peiró, J. M. (2005). Linking organizational resources and work engagement to employee performance and customer loyalty: The mediation of service climate. Journal of Applied Psychology, 90(6), 1217-1227.

Schaufeli, W. B., Bakker, A. B., \& Salanova, M. (2006). The measurement of work engagement with a short questionnaire: A cross-national study. Educational and Psychological Measurement, 66(4), 701-716.

Schaufeli, W. B., Taris, T. W., \& Van Rhenen, W. (2008). Workaholism, burnout, and work engagement: Three of a kind or three different kinds of employee well-being? Applied psychology, 57(2), 173-203.

Schein, E. H. (1965). Organizational psychology. Prentice-Hall.

Schwarz, C. A., \& Schalk, C. (1996). Natural Church Development. ChurchSmart Resources.

Seligman, M. E. P., Steen, T. A., Park, N., \& Peterson, C. (2005). Positive psychology progress: Empirical validation of interventions. American Psychologist, 60(5), 410-421.

Spector, P. E. (2017). Industrial and Organizational Psychology: Research and Practice (7th ed.). Wiley.

Spence, J. T., \& Robbins, A. S. (1992). Workaholism: Definition, measurement, and preliminary results. Journal of personality assessment, 58(1), 160-178.

Tett, R. P., \& Meyer, J. P. (1993). Job satisfaction, organizational commitment, turnover intention, and turnover: path analyses based on meta-analytic findings. Personnel Psychology, 46(2), 259-293.

Thiselton, A. C. (2000). The First Epistle to the Corinthians: A commentary on the Greek text. William B. Eerdmans Publishing.

Tims, M., Bakker, A. B., \& Derks, D. (2013). The impact of job crafting on job demands, job resources, and well-being. Journal of occupational health psychology, 18(2), 230-240.

Vandello, J. A., \& Cohen, D. (1999). Patterns of individualism and collectivism across the United States. Journal of Personality and Social Psychology, 77(2), 279-292.

Vecina, M. L., Chacón, F., Sueiro, M., \& Barrón, A. (2012). Volunteer engagement: Does engagement predict the degree of satisfaction among new volunteers and the commitment of those who have been active longer? Applied psychology, 61(1), 130-148.

Weiss, H. M. (2002). Deconstructing job satisfaction: Separating evaluations, beliefs and affective experiences. Human Resource Management Review, 12(2), 173-194. 